\title{
20. GENESIS AND SIGNIFICANCE OF GLAUCONITIC SEDIMENTS OF THE SOUTHWEST ROCKALL PLATEAU 1
}

\author{
Andrew C. Morton and Richard J. Merriman, British Geological Survey \\ and \\ John G. Mitchell, The University, Newcastle-upon-Tyne ${ }^{2}$
}

\begin{abstract}
Glauconite-rich sediments have been encountered at two horizons during drilling in the southwest Rockall Plateau. The younger of these horizons lies at the base of a deep-sea ooze sequence and is of early or middle Miocene age. Glauconite formed in situ during periods of nondeposition related to strong bottom-water currents, in water depths of as much as $2500 \mathrm{~m}$ - five times greater than previously accepted limits for glauconite formation. The older horizon, of early Eocene age, is a record of the major transgression coincident with the separation of Rockall and Greenland.

Isotopic age dating of the Miocene glauconites gives results in relatively close accord with their biostratigraphic age. However, an Eocene (NP12) glauconite gives a highly discrepant date (36.5 m.y. ago). One possible explanation is that the Eocene glauconites have continued to evolve after burial by the diagenetic uptake of potassium from the surrounding mud matrix, a possibility denied to the Miocene glauconites by the relative scarcity of available potassium in the nannofossil-foraminiferal ooze matrix.
\end{abstract}

\section{INTRODUCTION}

Concentrations of glauconite grains occur at two distinct stratigraphic horizons in the sediments of the southwest Rockall Plateau region drilled by DSDP Leg 81 (Fig. 1). One of these is at the base of the nannofossilforaminiferal oozes and chalks of the Miocene and Pliocene, and was noted at all the Leg 81 sites. The other lies within the early Eocene sequence and has been recognized at two Leg 48 sites (403 and 404) (Harrison et al., 1979; Odin, 1979) in addition to the Leg 81 Sites 553 and 555. This chapter describes the petrography and mineralogy of the glauconite associated with these horizons, reports on their $\mathrm{K}-\mathrm{Ar}$ radiometric age, and discusses their significance in both stratigraphic and paleoenvironmental terms.

Petrographical and mineralogical studies of the glauconitic horizons were performed using various techniques, including optical and scanning electron microscopy, electron microprobe analysis (using an energy-dispersive $\mathrm{X}$-ray analyzer), and X-ray diffraction. Conventional potassium-argon ages were determined for four of the samples (see Table 1) using the methods described by Mitchell (1972), but ensuring that the sample temperature never exceeded $30^{\circ} \mathrm{C}$ prior to analysis. Glauconite separations (approximately $1 \mathrm{~g}$ from each specimen) were performed electromagnetically.

The glauconite nomenclature used throughout this account is that of Bentor and Kastner (1965).

\footnotetext{
${ }^{1}$ Roberts, D. G., Schnitker, D., et al., Init. Repts. DSDP, 81: Washington (U.S. Gov Printing Office).

2 Addresses: (Morton) Petrology Unit, British Geological Survey, Keyworth NG12 SGG, United Kingdom; (Merriman) Petrology Unit, British Geological Survey, London SW7 2DE United Kingdom; (Mitchell) Dept. of Geophysics and Planetary Physics, The University, Newcastle-upon-Tyne NE1 7RU, United Kingdom.
}

\section{MIOCENE}

Abundant glauconite grains, set in a nannofossil-foraminiferal chalk matrix, occur in all the holes drilled during Leg 81 , at the base of deep-sea ooze sequence that characterizes the Neogene of the area (Section 5528-1 to 552-8-4, $45 \mathrm{~cm}$; Section $552 \mathrm{~A}-36-1$ to $552 \mathrm{~A}-36-3$, $140 \mathrm{~cm}$; Section 553A-8-1 to 553A-8-3, $130 \mathrm{~cm}$; Section 554A-4-1 to 554A-4-1, $25 \mathrm{~cm}$; and Section 555-24-1 to 555-26,CC). In all cases the glauconite increases downhole, reaching a maximum in the sediment immediately above the hiatus between the ooze and the underlying beds.

The greatest concentration of glauconite grains occurs at Site $552(10-40 \%)$ and the least at Site $555(1-$ $15 \%$ ); samples from Holes 553A and 554A contain $25 \%$ and $20 \%$ of glauconite, respectively. Grain sizes are mostly in the range $0.05-0.5 \mathrm{~mm}$ (very fine-medium sand), with a few grains reaching $0.7 \mathrm{~mm}$ across. Two distinct types of glauconite grain are present. Glauconite pellets are rounded, subrounded, or crescentic in shape, and internally consist of a random intergrowth of submicroscopic mineral glauconite flakes. The color of the pellets is uniformly dark green except where stained brown by secondary hydrated Fe-oxides. Most pellets of this type correspond to Triplehorn's (1966) glauconite type 8 (internal casts of microfossils), with foraminiferal and radiolarian tests forming the most common molds. Although a few pellets show desiccation cracks, they rarely possess partial coatings of concentric mineral glauconite flakes.

The second type of glauconite grain present has formed by replacement, mostly of volcanic particles. Grains of this type are rounded to subrounded in shape, have low sphericities, and vary from dark bottle-green to pale green in color. Texturally they are inhomogeneous and 


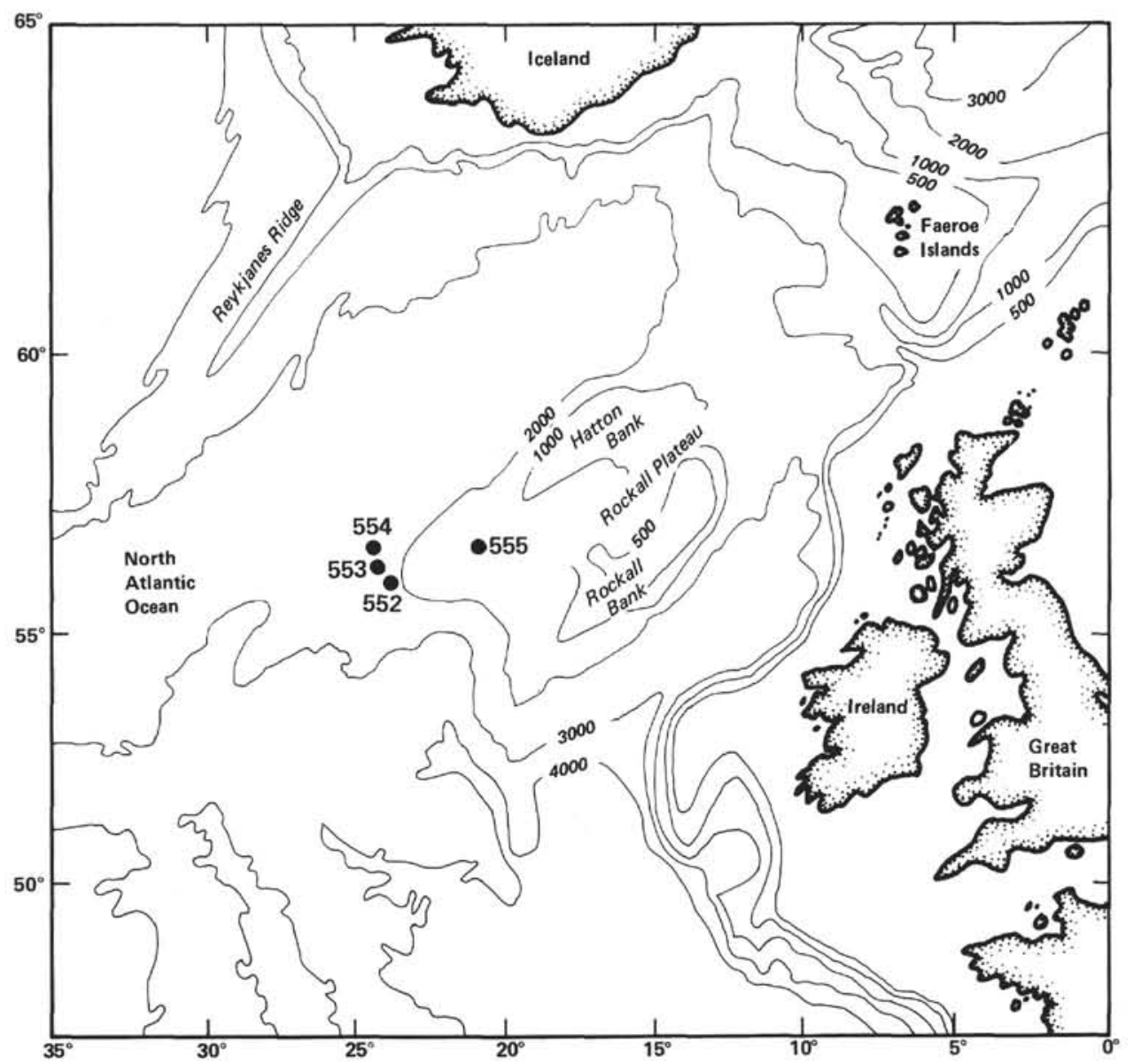

Figure 1. Map of North Atlantic area showing sites drilled by DSDP Leg 81 .

Table 1. Structural formulas for Eocene and Miocene glauconites based on $22(\mathrm{O}, \mathrm{OH}, \mathrm{F})$.

\begin{tabular}{llcc}
\hline & & Miocene $^{\mathrm{a}}$ & Eocene $^{\mathrm{b}}$ \\
\hline $\mathrm{IV}$ & $\mathrm{Si}$ & 7.58 & 7.54 \\
& $\mathrm{Al}$ & 0.42 & 0.46 \\
& $\mathrm{Al}$ & 0.69 & 0.33 \\
& $\mathrm{Fe}^{3+}$ & 1.92 & 2.32 \\
& $\mathrm{Fe}^{2+}$ & 0.40 & 0.50 \\
$\mathrm{VI} \quad \mathrm{Mg}$ & 1.02 & 0.83 \\
& $\mathrm{Ti}$ & 0.02 & 0.07 \\
& $\mathrm{Cr}$ & 0.01 & 0.01 \\
& $\mathrm{Mn}$ & 0.01 & 0.00 \\
& $\mathrm{Ca}$ & 0.13 & 0.03 \\
& $\mathrm{Na}$ & 0.41 & 0.37 \\
& $\mathrm{~K}$ & 0.98 & 1.14 \\
$\mathrm{Fe}^{3+} / \mathrm{Fe}^{2+}$ & 4.80 & 4.60 \\
$\Sigma\left(\mathrm{R}^{3+}+\mathrm{R}^{2+}\right)$ & 4.06 & 4.06 \\
$\Sigma \mathrm{R}^{3+}$ & 2.61 & 2.65 \\
$\Sigma \mathrm{A}$ & & 1.52 & 1.54 \\
\hline
\end{tabular}

a Based on averaged analyses from Sample 553-8-3, 124-126 cm (Table 2).

$b$ Based on averaged analyses from Sample 553A-11-4, 77-78 cm (Table 2).

commonly display ghost structures which have been inherited from volcanoclasts. Originally microcrystalline or hyalocrystalline lava grains show ghosts of feldspar microlites; subradiating and spherulitic aggregates of glau- conite flakes characterize devitrified glassy lava grains. Some glauconite grains are heavily charged with opaque dust, and possibly represent argillized basic glass. Other glauconite of replacement type includes several large (up to $5 \mathrm{~mm}$ across) particles of marl and tuffaceous sediment which contain glauconitic grains formed prior to their incorporation into the Miocene oozes. Partial coatings of concentric glauconite flakes are found on several glauconitized volcanoclasts at the base of Sites 552 and 555 . Desiccation cracks in some of these grains evidently formed after the glauconite coatings. In general, glauconitized volcanoclasts are between two and three times more abundant than glauconite pellets, with the greatest concentration occurring at Site 555 .

Fresh or little altered particles of microcrystalline lava (up to $0.5 \mathrm{~mm}$ across) occur in many of the glauconitic samples. One such particle (Sample 555-26-6, 140$142 \mathrm{~cm}$ ) displays a texture of flow-aligned plagioclase microlites reminiscent of trachytic texture (Plate 1, Fig. 1). In the same sample another basalt grain displays partial replacement and overgrowth by glauconite (Plate 1, Fig. 2). Fresh plagioclase with glauconitized ?glassy lava attached occurs in Sample 554A-4-2, 20-22 cm.

Mineralogically, the Miocene glauconites are dioctahedral $1 \mathrm{Md}$ mica polytypes with $20-40 \%$ of smectite interlayers, corresponding to Class 2 glauconite of Bentor and Kastner (1965). There are no consistent mineralogical differences between glauconite pellets formed as in- 
fillings and glauconite replacing volcanoclasts. However, a number of the pale-green glauconite grains contain phosphatic material in the form of carbonate-apatite. In color and texture these grains closely resemble the phosphatized glauconites from the Cretaceous Hibernian Greensands of Northern Ireland (Jeans et al., 1982). The phosphate is associated with a zeolite of the heulandite-clinoptilolite type in Sample 552A-36-3, 135$138 \mathrm{~cm}$, where it occurs as intergrowths of minute (up to $0.07 \mathrm{~mm}$ ) prismatic crystals within glauconitized vol- canoclasts. Clinoptilolite and phillipsite also occur as a late-stage cement in scattered areas (up to $0.3 \mathrm{~mm}$ across) of the marls.

Electron microprobe compositions of three Miocene glauconites are shown in Table 2 and results plotted in Figure 2. The main compositional variation is in the high $\mathrm{SiO}_{2}$ content of the glauconite filling a sponge spicule, with consequent low $\mathrm{Al}_{2} \mathrm{O}_{3}$ and $\mathrm{K}_{2} \mathrm{O}$. Glauconite infillings, in the form of pellets, and glauconite replacing the groundmass of a lava grain give closely similar analyses,

Table 2. Chemical composition of Leg 81 glauconites and celadonite determined by electron microprobe analysis. All iron calculated as $\mathrm{FeO}$.

\begin{tabular}{|c|c|c|c|c|c|c|c|c|c|c|c|c|c|c|c|}
\hline \multirow{2}{*}{$\begin{array}{c}\text { Sample } \\
\text { (interval in } \mathrm{cm} \text { ) }\end{array}$} & \multirow{2}{*}{$\begin{array}{c}\text { Nanno- } \\
\text { plankton } \\
\text { zone }\end{array}$} & \multirow{2}{*}{$\begin{array}{c}\text { Mode of } \\
\text { occurrence }\end{array}$} & \multicolumn{13}{|c|}{ Oxide $(\%)$} \\
\hline & & & $\mathrm{Si}$ & $\mathrm{Ti}$ & Al & $\mathrm{Cr}$ & $\mathrm{Fe}$ & $\mathrm{Mn}$ & $\mathrm{Mg}$ & $\mathrm{Ca}$ & $\mathrm{Na}$ & $\mathrm{K}$ & $\mathrm{Cl}$ & s & Total \\
\hline \multicolumn{16}{|l|}{ Hole 553A } \\
\hline \multirow[t]{3}{*}{$8-3,124-126$} & NN5 & Pellet & 53.4 & 0.2 & 7.0 & 0.0 & 18.9 & 0.1 & 5.1 & 0.7 & 1.4 & 5.7 & 0.6 & 0.2 & 93.3 \\
\hline & & Infilling spicule & 54.7 & 0.2 & 5.3 & 0.0 & 20.1 & 0.1 & 4.9 & 0.4 & 1.7 & 4.6 & 0.6 & 0.3 & 92.9 \\
\hline & & $\begin{array}{l}\text { Groundmass, } \\
\text { glauconitized lava } \\
\text { particle }\end{array}$ & 51.8 & 0.2 & 7.5 & 0.1 & 19.4 & 0.0 & 4.5 & 1.4 & 1.3 & 5.9 & 0.3 & 0.3 & 92.7 \\
\hline \multirow[t]{3}{*}{$11-4,77-78$} & NP12 & Pellet & 51.8 & 0.5 & 4.4 & 0.1 & 24.4 & 0.0 & 3.8 & 0.1 & 1.2 & 6.6 & 0.6 & 0.3 & 93.8 \\
\hline & & Infilling radiolarian test & 52.1 & 0.7 & 4.6 & 0.1 & 22.4 & 0.0 & 3.7 & 0.2 & 1.4 & 5.8 & 0.7 & 0.8 & 92.5 \\
\hline & & $\begin{array}{l}\text { Replacing igneous } \\
\text { particle }\end{array}$ & 51.8 & 0.6 & 4.8 & 0.0 & 22.8 & 0.0 & 4.0 & 0.2 & 1.3 & 6.1 & 0.8 & 0.5 & 92.9 \\
\hline \multirow[t]{2}{*}{$12, \mathrm{CC}(5-7)$} & NP10 & $\begin{array}{l}\text { Replacing volcanic } \\
\text { glass }\end{array}$ & 49.4 & 0.1 & 3.7 & 0.0 & 28.0 & 0.0 & 3.5 & 0.2 & 1.2 & 6.6 & 0.4 & 0.2 & 93.3 \\
\hline & & Celadonite needles & 47.1 & 0.1 & 3.4 & 0.0 & 12.7 & 0.0 & 5.9 & 0.2 & 0.7 & 8.8 & 0.9 & 0.4 & 80.2 \\
\hline \multicolumn{16}{|l|}{ Hole 555} \\
\hline \multirow[t]{2}{*}{$27-1,27-28$} & NP11 & Pellet & 54.4 & 0.1 & 4.6 & 0.1 & 23.9 & 0.2 & 4.3 & 0.2 & 1.6 & 4.8 & 0.3 & 0.1 & 94.6 \\
\hline & & Infilling spicule & 53.7 & 0.1 & 4.5 & 0.1 & 23.5 & 0.0 & 4.7 & 0.2 & 1.2 & 6.4 & 0.2 & 0.0 & 94.6 \\
\hline
\end{tabular}

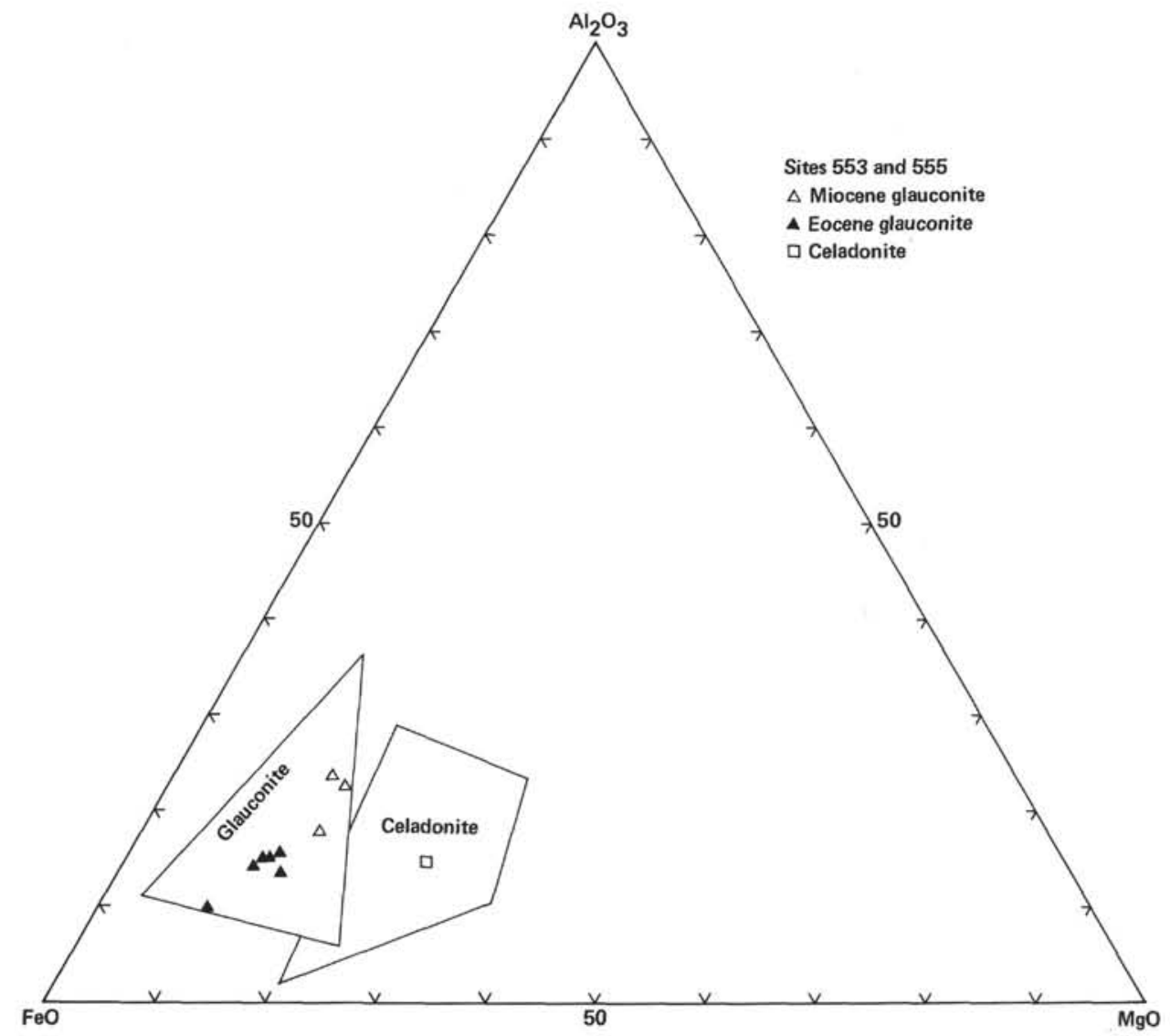

Figure 2. Compositions of glauconites and one celadonite from Sites 553 and 555. Glauconite and celadonite areas delineated according to data in Buckley et al. (1978). 
indicating that glauconite composition is controlled by the geochemistry of the sedimentary environment rather than by that of the host. A tendency for Miocene and Eocene glauconite compositions to form distinct groups (Fig. 2) is further evidence of this control. The Miocene glauconites plot towards relatively $\mathrm{Fe}$-poor compositions in the triangular area of Figure 2 delineated by plotting glauconite analyses given in Buckley et al. (1978). Potash values obtained by electron microprobe are consistently higher than those derived from $\mathrm{K}-\mathrm{Ar}$ analysis (Table 3). This possibly reflects intragrain variation in the distribution of interlayered material: Cores of glauconite grains, which tend to be the regions analyzed by electron microprobe, generally contain fewest interlayers and hence higher $\mathrm{K}_{2} \mathrm{O}$ than do cortex regions. Results in Table 3 are thus representative of the overall $\mathrm{K}_{2} \mathrm{O}$ content of the glauconite grains. A structural formula calculated from an average of three glauconite analyses from Sample 553-8-3, $124-126 \mathrm{~cm}$ is shown in Table 1 . The $\mathrm{Fe}^{3+}: \mathrm{Fe}^{2+}$ ratio of $3: 33$ was chosen to give ionic totals compatible with the criteria established by Buckley et al. (1978), i.e., for glauconite, $\Sigma \mathrm{R}^{3+}$ is $1.19-1.49$ and $\Sigma\left(\mathrm{R}^{3+}+\mathrm{R}^{2+}\right) \simeq 2.0$. Low values of total interlayer cations ( $\Sigma \mathrm{A})$ are characteristic of Class 2 glauconites, reflecting greater occupancy of interlayer sites by $\mathrm{Ca}^{2+}$ than by $\mathrm{K}^{+}$. Similar values are reported by Buckley et al. (in press) from interlayered Class 2 glauconites occurring in the L Cretaceous Folkestone Beds of S.E. England; these glauconite grains contain a high proportion of altered volcanoclasts, according to Jeans et al. (1982). Using the curves of Cimbálniková (1971), the ionic $\mathrm{K}^{+}$value of 1.06 indicates approximately $35 \%$ of expansible interlayers in the Miocene glauconite, a figure which may be higher overall when allowance is made for the lower $\mathrm{K}_{2} \mathrm{O}$ figures shown in Table 3.

Conventional potassium-argon age determinations were made on three samples of Miocene glauconite, one each from Sites 552, 553, and 555 (Table 1). The results are all compatible with their biostratigraphic age, with two NN5 samples giving dates of $15.8 \pm 0.8$ m.y. ago and $16.2 \pm 0.9$ m.y. ago, and an NN3 sample giving a date of $23.5 \pm 0.6 \mathrm{~m}$.y. ago.

Although limited to the early or middle Miocene, the exact biostratigraphic age of the glauconitic horizons varies from site to site. At Sites 552 and 553, the base of the unit lies within nannoplankton Zone NN5, in Hole 554A

Table 3. Results of $\mathrm{K}-\mathrm{Ar}$ isotopic age determinations on Leg 81 glauconites.

\begin{tabular}{|c|c|c|c|c|c|}
\hline $\begin{array}{c}\text { Sample } \\
\text { (interval in } \mathrm{cm} \text { ) }\end{array}$ & $\begin{array}{l}\text { Nanno- } \\
\text { plankton } \\
\text { zone }\end{array}$ & $\begin{array}{l}\mathrm{K}_{2} \mathrm{O} \\
(\%)\end{array}$ & $\begin{array}{l}\text { Radiogenic }{ }^{40} \mathrm{Ar} \\
\left(\mathrm{nm}^{3} \mathrm{~g}^{-1}\right)\end{array}$ & $\begin{array}{l}\text { Atmospheric } \\
\text { contamination }\end{array}$ & $\begin{array}{l}\text { Age } \pm 1 \sigma \\
\text { (m.y. ago) }\end{array}$ \\
\hline \multicolumn{6}{|l|}{ Hole 552A } \\
\hline $36-3,135-138$ & NN5 & $4.52 \pm 0.18$ & $(2.32 \pm 0.06) 10^{-3}$ & 77.6 & $15.8 \pm 0.8$ \\
\hline \multicolumn{6}{|l|}{ Hole $553 \mathrm{~A}$} \\
\hline $\begin{array}{l}8-3,124-126 \\
11-4,77-78\end{array}$ & $\begin{array}{l}\text { NNS } \\
\text { NP12 }\end{array}$ & $\begin{array}{l}3.99 \pm 0.19 \\
4.98 \pm 0.05\end{array}$ & $\begin{array}{l}(2.10 \pm 0.06) 10^{-3} \\
(5.93 \pm 0.08) 10^{-3}\end{array}$ & $\begin{array}{l}90.2 \\
49.0\end{array}$ & $\begin{array}{l}16.2 \pm 0.9 \\
36.5 \pm 0.6\end{array}$ \\
\hline \multicolumn{6}{|l|}{ Hole 555} \\
\hline $26-6,140-142$ & $\mathrm{NN} 3$ & $4.33 \pm 0.01$ & $(3.31 \pm 0.08) 10^{-3}$ & 72.6 & $23.5 \pm 0.6$ \\
\hline
\end{tabular}

within NN7/NN8, and within NN3 at Site 555. This variation reflects the diachronous nature of the onset of drift deposition, after a period of nondeposition or erosion related to strong bottom-water currents. The oozes and associated glauconitic material accumulated in water depths similar to those of the present date, i.e., about $2500 \mathrm{~m}$ for Sites 552, 553, and 554, and about $1600 \mathrm{~m}$ for Site 555 (Murray, this volume). The glauconites either result from glauconitization of volcanoclasts or, less commonly, represent infillings of bioclasts. Material forming the latter must have been present at the site of accumulation, probably in the form of a bottom suspension or an unstable sediment of flocculated particles. Mineralogically, this material may have been an iron-rich montmorillonite. That it existed from time to time as local sediment is further indicated by partial or, more rarely, complete accretionary coatings of glauconite on some volcanoclasts. Volcanogenic debris appears to be the only allochthonous sediment reaching the site of accumulation in significant amounts. Submarine outcrops of Paleogene lavas scoured by bottom currents must have been a readily available source of this material. The larger volcanoclasts may have been partially argillized prior to transport, but certainly the process of glauconitization continued in situ. Finer material probably reached depositional sites as fully argillized particles, providing the sediment necessary for infillings and occasional coatings of accumulated debris. Initially the process of glauconite formation operated as an open system, as infillings, coatings, and partially argillized volcanoclasts exchanged cations with seawater, gaining $\mathrm{K}^{+}$and, by oxidation, $\mathrm{Fe}^{3+}$, with increased loss of $\mathrm{Ca}^{2+}, \mathrm{Na}^{+}$, and possibly $\mathrm{Al}^{3+}$. However once sufficient ooze had accumulated to bury the glauconite, its evolution toward a fully $\mathrm{K}$-exchanged mica structure was arrested, because of the lack of potassium in the enclosing ooze. As a result these somewhat K-deficient Miocene glauconites give biostratigraphically concordant ages.

Hitherto, water depths in excess of $500 \mathrm{~m}$ were not considered conducive to glauconite formation (McRae, 1972; Odin and Stephan, 1981; Odin and Matter, 1981). Several compelling lines of argument arising from these studies lead to the conclusion that glauconite can form in water at least five times this depth. Firstly, the absence of significant amounts of terrigenous detritus, coupled with the absence of shallow water benthic foraminifers (Murray, this volume), rules out the possibility of glauconite forming penecontemporaneously in shallow water with subsequent displacement from the shelf to the drilled locations. Secondly, the mineralogical and chemical differences between Eocene and Miocene glauconites preclude the possibility of deriving all but a few grains of tuff and marl from Eocene glauconites known to exist in the area. Moreover, Miocene glauconites give radiometric ages concordant with their biostratigraphic ages, whereas Eocene glauconites are strongly discordant. Thirdly there is petrographical evidence, in the form of accretionary coating and infilled bioclasts, that glauconite, or its smectitic precursor, was present at the site of accumulation. The glauconite in the Miocene oozes therefore represent in situ formation in water 
depths of up to $2500 \mathrm{~m}$ in conditions of low sedimentation rates related to strong bottom currents.

\section{EOCENE}

At Sites $403,404,553$, and 555 a major accumulation of glauconite occurs in the lower Eocene sediments. The base of the horizon is coincident with reflector 1 of Roberts et al. (1979) and Roberts (this volume). It marks a major change in depositional environment from the marginal marine and estuarine conditions of the Paleocene and earliest Eocene to normal open marine conditions, indicated by a dramatic change in the ratio of dinoflagellates to spores and pollen (Brown and Downie, this volume), the appearance of abundant biosiliceous material, and an increased diversity in nannofossil and planktonic foraminiferal assemblages.

At Site 553 well-rounded glauconite grains comprise about $35 \%$ of the top of the glauconitic horizon (Sample $553 \mathrm{~A}-11-4,77-78 \mathrm{~cm}$ ). They lie in a matrix of pale green clay which is largely composed of smectite-interlayered Class 2 glauconite and discrete smectite (possibly Fe-montmorillonite), with minor amounts of celadonite, clinoptilolite, and carbonate-apatite. Bioclastic debris, showing varying degrees of argillization, is scattered through the matrix. The glauconite grains range in size from 0.1 to $2 \mathrm{~mm}$ and most possess a complete or partial accretionary coating of fibroconcentric clay which is commonly brown-stained by hydrated iron oxides. Many of the larger grains and those with low sphericity are glauconitized volcanoclasts, whereas the more highly spherical grains appear to be infilled and replaced siliceous bioclasts (Plate 1, Fig. 3). The underlying glauconitic clays (Sample 553A-12-3, 142-144 cm) have a brown tuffaceous clay matrix mostly consisting of dioctahedral smectite with scattered intergrowths of prismatic clinoptilolite. Here glauconite grains are also rounded, with accretionary coatings of glauconite welldeveloped (Plate 1, Fig. 4), but lack brown oxidation products. Desiccation cracks are commonly developed in the glauconite grains, and a high proportion are fragmented, in extreme cases producing a litter of glauconite fragments in the matrix.

The majority of the glauconite grains, both infillings and replacement types, are composed mostly of a dioctahedral 1Md mica polytype containing up to $25 \% \mathrm{smec}-$ tite interlayers (Class 2 glauconite). Many also contain varying amounts of a well-crystallized mica, either a Class 1 glauconite sensu stricto, of Bentor and Kastner (1965), or celadonite. Minor amounts of discrete smectite, clinoptilolite, and carbonate-apatite also occur in the grains. Some dark-green grains consist largely of dioctahedral smectite, possibly nontronite.

In the top of the tuff immediately underlying the glauconitic clays at Site 553 (Sample 553A-12-5, 30-32 cm), glauconite partially or completely replaces a variety of volcanic particles. The latter range from microcrystalline and hyalocrystalline vesicular basalt grains to entirely glassy types including many highly vesicular pumice grains (Plate 1, Fig. 5). Most of these particles, up to $4 \mathrm{~mm}$ across, were rounded and in many cases have acquired partial accretionary glauconite coatings, now brown-stained, prior to their incorporation into the sediment. More juvenile basaltic volcanoclasts, subangular and poorly glauconitized, occur with the glauconite grains within a brown clay matrix mostly composed of smectite and rich in shards (up to $0.08 \mathrm{~mm}$ across) and pumice fragments. Subsequent to glauconitization, the tuff was cemented by celadonite and phillipsite. Bluegreen celadonite forms a patchy late cement in the clay matrix (Plate 1, Fig. 6) and replaces bioclastic debris and the glassy groundmass of juvenile volcanoclasts. The presence of late celadonite associated with phillipsite in the matrix of some tuffs suggests that low-temperature zeolite-facies alteration occurred after the formation of glauconite. Zeolite zones with associated celadonite characterize the upper portions of a fossil hydrothermal system in Eastern Icelandic Tertiary lavas; alteration temperatures in the upper zeolite zone were probably below $120^{\circ} \mathrm{C}$ (Mehegan and Robinson, 1982). Although relatively low, such temperatures are significantly higher than those prevailing at the sediment-water interface where glauconite forms, and are evidently sufficient to produce the relatively well-crystallized $1 \mathrm{M}$ mica polytype typical of celadonite.

At Site 555, the top of the glauconitic horizon contains about $5 \%$ of glauconite grains scattered through a smectite-clay tuff, rich in brown glass shards and unaltered bioclastic debris (Sample 555-27-1, 27-28 cm). In samples below this horizon (Samples 555-32-2, 26-28 cm and 555-32-3, 102-103 cm), glauconite grains form up to $10 \%$ of a sandy tuffaceous clay. The grains, up to 0.3 $\mathrm{mm}$ across, range in shape from well rounded to subangular and are mostly glauconitized volcanoclasts, with a few infilled and replaced bioclasts and rare glauconitized biotite flakes. Angular grains of quartz and alkali-feldspar are conspicuous, forming perhaps $10 \%$ of the sediment, and are clearly of terrigenous origin. However, much of the sediment is volcanogenic, consisting of a variety of microcrystalline and partly glassy basaltic particles and clinoptilolite-replaced glass shards in a smectite matrix. In the most glauconitic horizons at Site 555 (Samples 33-2, 107-109 cm; 33-5, 18-20 cm; and $34-2,110-112 \mathrm{~cm}$ ), dark-green, deeply cracked grains form up to $30 \%$ of tuffaceous, smectite- and clinoptilolite-rich clays. It is notable that none of the tuffaceous glauconitic clays at Site 555 contain celadonite, in contrast with the extensive occurrence of this mineral in similar lithologies at Site 553.

Electron microprobe analyses of grains from the glauconitic clay horizon at Sites 553 and 555 are shown in Table 2. They show little significant difference in glauconite compositions, whether occurring as infilling or replacing bioclastic or volcanoclastic material. However glauconite replacing glass in underlying tuffs in Hole $553 \mathrm{~A}(12, \mathrm{CC}, 5-7 \mathrm{~cm})$ is considerably more iron-rich than other Eocene glauconites. Plots of oxides of the main octahedral cations (Fig. 2) clearly illustrate the main compositional difference between Miocene and Eocene glauconite compositions: the latter are more ironrich and less aluminous, whereas $\mathrm{MgO}$ varies little, excluding coexisting celadonite. This results in greater octahedral occupancy by $\mathrm{Fe}^{3+}$ in the structural formula 
shown in Table 1, reflecting the more strongly oxidizing, shallow water conditions under which glauconite formation took place in the Eocene. Total interlayer cations $(\Sigma \mathrm{A})$ is low, reflecting the interlayered Class 2 nature of the Eocene glauconite, but the latter show consistently higher $\mathrm{K}_{2} \mathrm{O}$ and lower $\mathrm{CaO}$ contents than the Miocene glauconites. Using the $\mathrm{K}^{+}$value of 1.14 from Table 1 , Cimbálniková's (1971) curve indicates approximately $25 \%$ expansible layers in the Eocene glauconites.

Grains from one sample of the lower Eocene glauconitic clays (Sample 553A-11-4, 77-78 cm) were analyzed by conventional $\mathrm{K}-\mathrm{Ar}$ techniques. The apparent age of $36.5 \pm 0.6 \mathrm{~m} . \mathrm{y}$. ago (Table 1 ) is clearly discordant with the biostratigraphic assignment (NP12), in contrast with the generally concordant ages given by the Miocene glauconites. Both the Eocene and Miocene glauconites would be considered unsuitable $\mathrm{K}-\mathrm{Ar}$ age dating material by Odin et al. (1978), because low $\mathrm{K}_{2} \mathrm{O}$ content $(<7.0 \%)$ is believed to indicate a partially "evolved" glauconite which is not therefore a closed system isotopically. A possible explanation of the concordancy of the Miocene ages relates to the potassium-poor nature of the enclosing carbonate matrix. In the case of the Eocene glauconite, the potassium-rich nature of the clay matrix suggests that the exchange of $\mathrm{K}^{+}$ions between the glauconite grains and the matrix could have continued after burial.

Biostratigraphic and magnetostratigraphic studies indicate that the deposition of the glauconitic clay horizon began virtually synchronously at all sites, occurring in late NP10 times (Backman, this volume). At all sites except 553 it occurs within dinoflagellate Zone Ib (Costa and Downie, 1979; Brown and Downie, this volume); at Site 553 the base coincides with the base of Zone II (Brown and Downie, this volume). It occurs just below the base of Magnetic Anomaly 24B (Hailwood, 1979; Krumsiek, this volume), again except at Site 553 where the normally magnetized zone appears to extend anomalously low in the hole. This may be a feature of lowtemperature hydrothermal activity at Site 553, for in addition to acquiring potassium during replacement by celadonite, vitroclastic material in the tuffs beneath the glauconitic clays has been enriched in iron (Morton and Keene, this volume). The anomalous normal magnetization could be the result of overprinting (Hailwood, pers. comm.), with tuffs acquiring the magnetization of the overlying glauconitic clays when the system became closed, during Anomaly 24B chron.

It is clear that the glauconitic horizon marks a major transgression over the southwest Rockall Plateau in late NP10 times. This transgression was coincident with the virtual cessation of explosive volcanism (Morton and Keene, this volume) and with the discontinuation of supply of terrigenous clastics from Greenland (Morton, this volume). Clearly, therefore, it represents the final separation of Rockall and Greenland.

\section{CONCLUSIONS}

The two major glauconite concentrations in Leg 81 sediments were deposited in quite different environments. Miocene glauconites occur at the base of a deep-sea ooze and chalk succession and represent in situ formation of glauconite in depths far exceeding previously accepted limits. The biostratigraphic age of the Miocene glauconites varies somewhat from site to site reflecting the diachronous nature of the onset of drift deposition. In contrast the genesis of the early Eocene glauconites took place in shallow marine conditions during a hiatus related to a major transgression in nannoplankton Zone NP10. This transgression was a result of the separation of Greenland and Rockall.

Although both Eocene and Miocene glauconites appear to be mineralogically and chemically unsuitable for $\mathrm{K}-\mathrm{Ar}$ dating using the criteria of Odin et al. (1978), the younger grains produced stratigraphically concordant results. Miocene glauconites gave dates of $15.8 \pm 0.8$ and $16.2 \pm 0.9$ m.y. ago for samples within NN5 and $23.5 \pm 0.6$ for one within NN3. The discordant Eocene date of $36.5 \pm 0.6$ m.y. from a sample within NP12 may be the result of continued exchange of potassium between enclosing matrix and glauconite grains after burial. In the case of the Miocene glauconites, potassium exchange was probably arrested at an early diagenetic stage following burial in a potassium-poor matrix of biogenic carbonate ooze.

\section{ACKNOWLEDGMENTS}

Mike Styles advised and guided us on the electron microprobe and also provided computer programs for calculating structural formulas. This chapter is published by permission of the Director, British Geological Survey (N.E.R.C.).

\section{REFERENCES}

Bentor, Y. K., and Kastner, M., 1965. Notes on the mineralogy and origin of glauconite. J. Sediment. Petrol., 35:155-166.

Buckley, H. A., Bevan, J. C., Brown, K. M., Johnson, L. R., and Farmer, V. C., 1978. Glauconite and celadonite: Two separate mineral species. Mineral. Mag., 42:373-382.

Buckley, H. A., Easton, A. J., and Johnson, L. R., in press. Compositional variations in glauconite. Mineral. Mag.

Cimbálníková, A., 1971. Chemical variability and structural heterogeneity of glauconites. Am. Mineralogist., 56:1385-1392.

Costa, L. I., and Downie, C., 1979. Cenozoic dinocyst stratigraphy of Sites 403 to 406 (Rockall Plateau), IPOD, Leg 48. In Montadert, L., Roberts, D. G., et al., Init. Repts. DSDP, 48: Washington (U.S. Govt. Printing Office), 513-529.

Hailwood, E. A., 1979. Paleomagnetism of late Mesozoic to Holocene sediments from the Bay of Biscay and Rockall Plateau, drilled on IPOD Leg 48. In Montadert, L., Roberts, D. G., et al., Init. Repts. DSDP, 48: Washington (U.S. Govt. Printing Office), 305-339.

Harrison, R. K., Knox, R. W. O'B., and Morton, A. C., 1979. Petrography and mineralogy of volcanogenic sediments from DSDP Leg 48, southwest Rockall Plateau, Sites 403 and 404. In Montadert, L., Roberts, D. G., et al., Init. Repts. DSDP, 48: Washington (U.S. Govt. Printing Office), 771-785.

Jeans, C. V., Merriman, R. J., Mitchell, J. G., and Bland, D. J., 1982. Volcanic clays in the Cretaceous of southern England and northern Ireland. Clay Miner., 17:105-156.

McRae, S. G., 1972. Glauconite. Earth-Sci. Rev., 8:397-440.

Mehegan, J. M., Robinson, P. T. and Delaney, J. R., 1982. Secondary mineralization and hydrothermal alteration in the Reydarfjordur drill core, eastern Iceland. J. Geophys. Res., 87:6511-6524.

Mitchell, J. G., 1982. Potassium-argon ages from the Cheviot Hills, north England. Geol. Mag., 109:421-426.

Murray, J. W., 1979. Cenozoic biostratigraphy and paleoecology of Sites 403 to 406 based on the foraminifers. In Montadert, L., Roberts, D. G., et al., Init. Repts. DSDP, 48: Washington (U.S. Govt. Printing Office), 415-430. 
Odin, G. S., 1979. Remarks concerning glauconitic materials collected during Leg 48. In Montadert, L., Roberts, D. G., et al., Init. Repts. DSDP, 48: Washington (U.S. Govt. Printing Office), 787-789.

Odin, G. S., Curry, D., and Hunziker, J. C., 1978. Radiometric dates from NW European glauconites and the Palaeogene time-scale. $J$. Geol. Soc. Lond., 135:481-497.

Odin, G. S., and Matter, A., 1981. De glauconiarum origine. Sedimentology, 28:611-641.

Odin, G. S., and Stephan, J. F., 1982. The occurrence of deep water glaucony from the Eastern Pacific: The result of in situ genesis or subsidence? In Watkins, J. S., Moore, J. C., et al., Init. Repts. $D S D P, 66$ : Washington (U.S. Govt. Printing Office), 419-428.

Roberts, D. G., Montadert, L., and Searle, R. C., 1979. Western Rockall Plateau: Stratigraphy and structural evolution. In Montadert, L., Roberts, D. G., et al., Init. Repts. DSDP, 48: Washington (U.S. Govt. Printing Office), 1061-1088.

Triplehorn, D. M., 1966. Morphology, internal structure and origin of glauconite pellets. Sedimentology, 6:247-266.

Date of Acceptance: August 29, 1983 


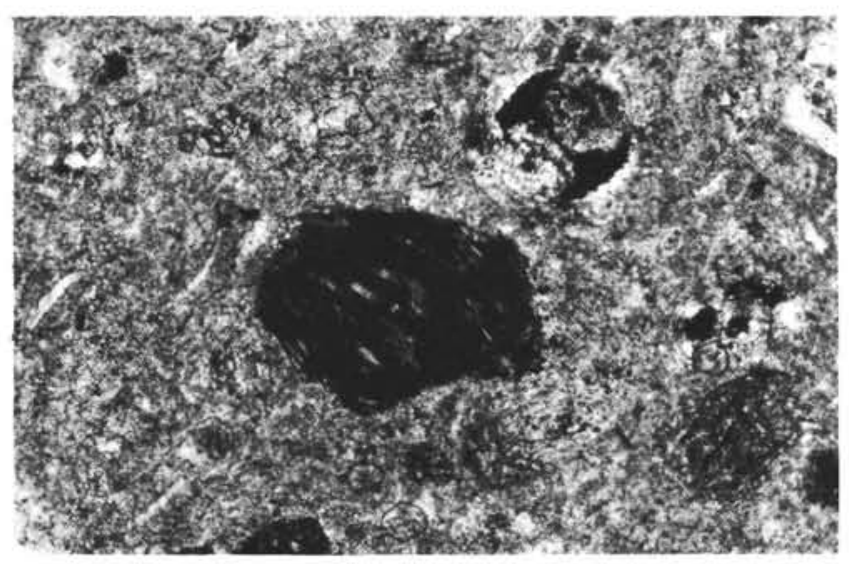

1
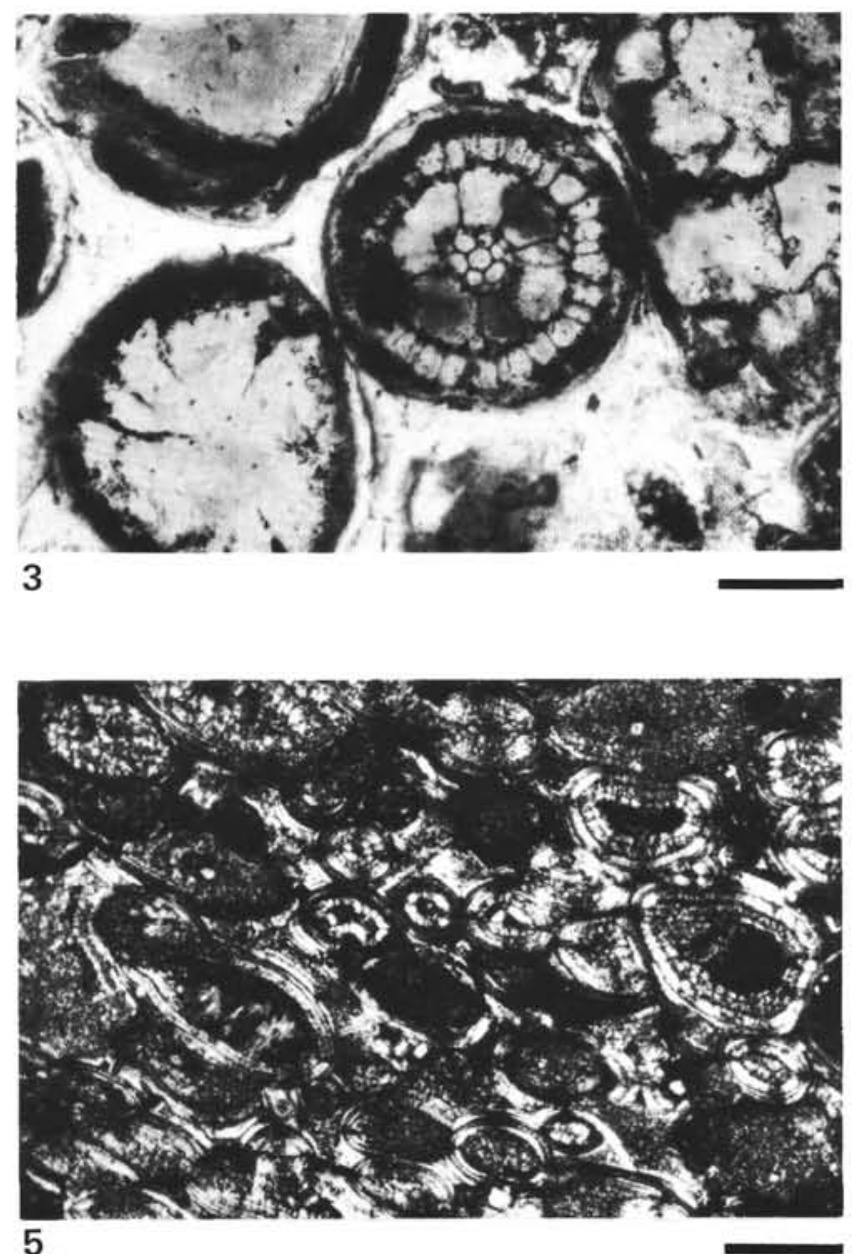

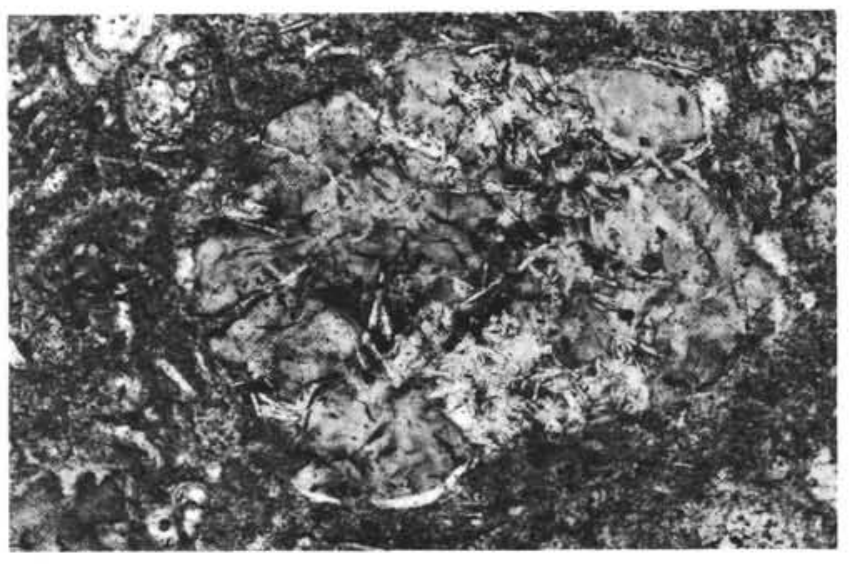

2
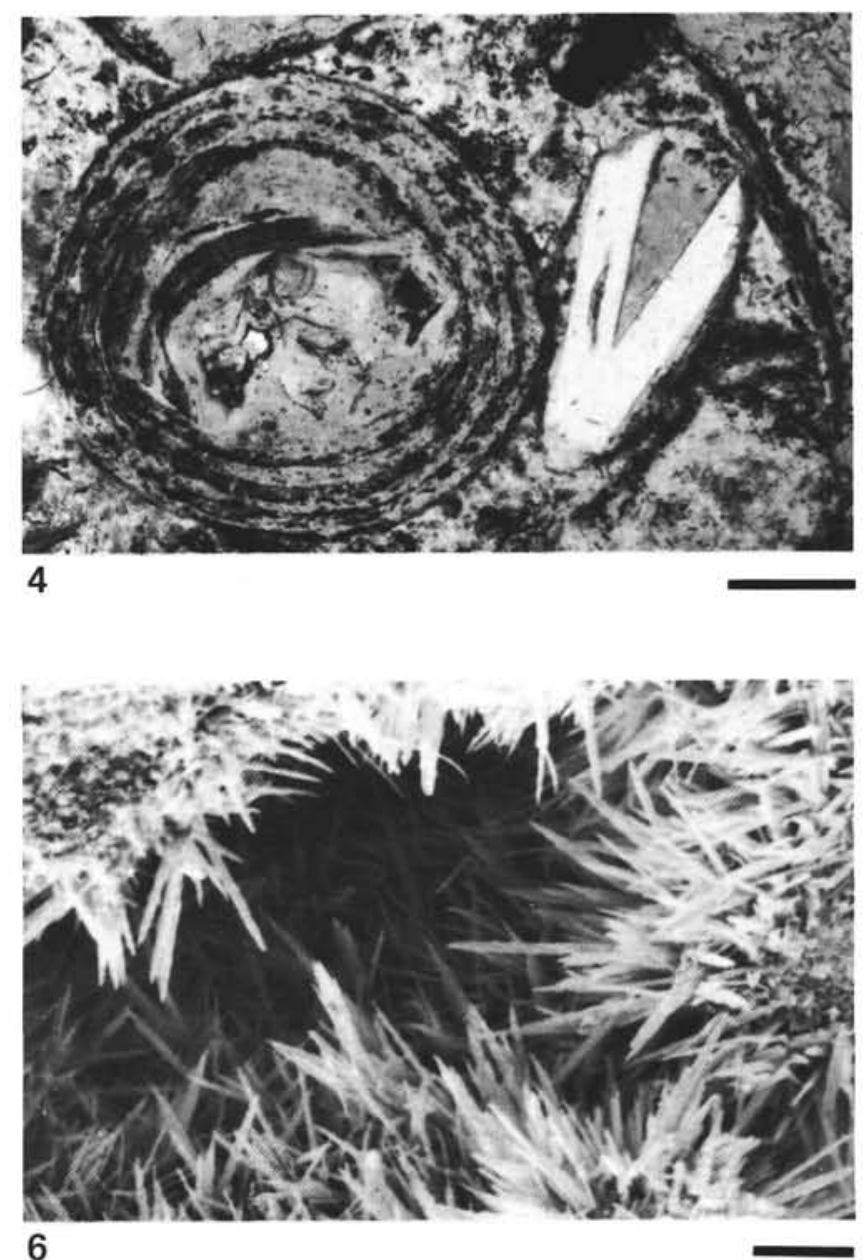

Plate 1. Photomicrographs of Miocene and Eocene glauconitic sediments from DSDP Leg 81, Sites 553 and 555. (Figs. 1-5 were taken under a polarizing microscope; Fig. 6 is a scanning electron micrograph.) 1. Flow-aligned plagioclase microlites in basalt grain in Miocene chalk ooze; Sample 555-26-6, 140-142 cm (scale bar $=100 \mu \mathrm{m}$; crossed polars). 2. Glauconite replacing basalt grain in Miocene chalk ooze; Sample 55526-6, 140-142 cm (scale bar $=40 \mu \mathrm{m}$; plane polarized light). 3. Glauconite infilling and replacing a siliceous bioclast in Eocene glauconitic clay. Sample 553A-11-4, 77-78 cm (scale bar $=100 \mu \mathrm{m}$; plane polarized light). 4. Accretionary glauconite coating glauconitized volcanoclast in Eocene tuffaceous glauconitic clay; Sample 553A-12-3, 142-144 cm (scale bar $=100 \mu \mathrm{m}$; plane polarized light). 5. Fibroradiating glauconite replacing vesicular glass in Eocene glauconitic tuff. Sample 553A-12-5, 30-32 cm (scale bar $=100 \mu \mathrm{m}$; crossed polars). 6. Needles of blue-green celadonite forming a late cement in Eocene glauconitic tuff. Sample 553A-12-5, 30-32 cm (scale bar $=10 \mu \mathrm{m}$ ). 